\title{
STAT5-mediated self-renewal
}

\section{of normal hematopoietic and leukemic stem cells}

\author{
Hein Schepers, ${ }^{1,2}$ Albertus T.J. Wierenga, ${ }^{1,3}$ Edo Vellenga ${ }^{1}$ and Jan Jacob Schuringa ${ }^{1, *}$
}

\begin{abstract}
'Department of Experimental Hematology; University Medical Center Groningen; Groningen, The Netherlands; ${ }^{2}$ Department of Stem Cell Biology; University Medical Center Groningen; Groningen, The Netherlands; ${ }^{3}$ Department of Laboratory Medicine; University Medical Center Groningen; Groningen, The Netherlands
\end{abstract}

Keywords: human hematopoietic stem cells, self-renewal, leukemia, cell type-specific signaling, leukemic transformation

The level of transcription factor activity critically regulates cell fate decisions such as hematopoietic stem cell self-renewal and differentiation. The balance between hematopoietic stem cell self-renewal and differentiation needs to be tightly controlled, as a shift toward differentiation might exhaust the stem cell pool, while a shift toward self-renewal might mark the onset of leukemic transformation. A number of transcription factors have been proposed to be critically involved in governing stem cell fate and lineage commitment, such as Hox transcription factors, c-Myc, Notch1, $\beta$-catenin, C/ebp $\alpha$, Pu. 1 and STAT5. It is therefore no surprise that dysregulation of these transcription factors can also contribute to the development of leukemias. This review will discuss the role of STAT5 in both normal and leukemic hematopoietic stem cells as well as mechanisms by which STAT5 might contribute to the development of human leukemias.

\section{Introduction}

Signal Transducer and Activator of Transcription 5 (STAT5) is widely expressed throughout the hematopoietic system, both in stem and progenitor cells as well as in committed erythroid, myeloid and lymphoid cells. ${ }^{1-3}$ Indeed, it is not surprising that STAT5 can be activated by a wide variety of cytokines and growth factors. ${ }^{3-5}$ These include cytokines and growth factors that can signal through the Interleukin 3 (IL3)-receptor family [IL3, IL5, Granulocyte-Macrophage Colony Stimulating Factor (GMCSF)], through the common $\gamma$-chain receptor family (IL2, IL7, IL9, IL12, IL15), through single chain receptors [Erythropoietin (EPO), Thrombopoietin (TPO), Growth Hormone (GH), prolactin, Granulocyte-Colony Stimulating Factor (G-CSF)], through class II receptors [Interferon $\alpha$ (IFN- $\alpha$ ), IFN- $\gamma$, IL22] or through tyrosine kinase receptors [Stem Cell Factor (SCF), Platelet Derived Growth Factor (PDGF), Epidermal growth Factor (EGF)] (Fig. 1). In most cases, Janus Kinase (JAK) tyrosine kinase activity mediates STAT5 tyrosine phosphorylation, and STAT5 can be activated by JAK1, 2 or 3, depending on the cytokine-activated receptor complex. Alternatively, the tyrosine kinase receptor family can also induce STAT5 phosphorylation in a JAK-independent manner. While STAT5 is expressed in the

*Correspondence to: Jan Jacob Schuringa; Email: j.schuringa@int.umcg.nl Submitted: 11/29/11; Revised: 01/10/12; Accepted: 01/11/12

http://dx.doi.org/10.4161/jkst.19316 majority of hematopoietic cell types, the cytokine receptor expression is much more tissue-specific. Thus, specific cytokines are able to induce STAT5 activity in subsets of cell types only. ${ }^{6}$ For example, cytokines that activate STAT5 in the most immature human hematopoietic stem compartment include $\mathrm{SCF}^{7}$ and TPO. ${ }^{8}$ These cytokines have been shown to promote long-term hematopoiesis in vitro, ${ }^{9}$ and hypersensitivity to TPO in $\mathrm{Lnk}^{-1-}$ mice resulted in elevated stem cell self-renewal, which coincided with increased levels of STAT5 activity. ${ }^{10}$ Within the erythroid compartment, STAT5 is activated by EPO, ${ }^{11}$ where STAT5 fulfills an important anti-apoptotic role by upregulating $\mathrm{Bcl}-\mathrm{X}_{\mathrm{l}},{ }^{12-15}$ although a more direct role in initiating erythroid commitment might exist as well. ${ }^{16-18}$ In myeloid cells, STAT5 can be activated by a variety of cytokines, including IL3, IL5, GM-CSF and CSF1 (reviewed in ref. 3). Although initially in STAT $5 \mathrm{AB}^{\Delta \mathrm{N} / \Delta \mathrm{N}}$ mice myelopoiesis appeared to be relatively unaffected, ${ }^{19}$ it is likely that in myeloid cells many of the signals initiated by e.g., IL-3 and GM-CSF are, at least in part, mediated by STAT $5,{ }^{20,21}$ thereby regulating myeloproliferation or antiapoptosis. ${ }^{22-24}$ During myelosuppression, mice completely deficient of STAT5AB failed to produce enhanced levels of neutrophils and were unable to respond to GM-CSF. ${ }^{25}$ IL5induced STAT5 activation is required for the induction of eosinophil differentiation. ${ }^{26}$ Lymphoid development is severely impaired in STAT5 ${ }^{-1-}$ mice. ${ }^{27}$ STAT5 activation is required for IL2-induced $T$ cell proliferation and the production of NK cells, ${ }^{28,29}$ or for IL7-mediated B cell expansion. ${ }^{30}$

As summarized in Table 1 and Figure 1B, a wide variety of genetic defects in myeloid leukemias and myeloproliferative diseases (MPDs) result in activation of the STAT5 pathway, including mutations in Flt3 and cKit receptors, JAK2 mutations, translocations such as TEL-PDGFRa, and Bcr-Abl, but also as a result of increased cytokine signaling. Numerous functional studies have indicated that aberrant activation of STAT5 can contribute to the process of leukemic transformation. Downstream of Flt3-ITD (Internal Tandem Duplication) mutations, STAT5 is strongly activated via two tyrosine residues within the Flt3 receptor, Y589 and Y592 that act as docking sites for the SH2 domain of STAT5 molecules. ${ }^{31}$ Mutation of these residues into phenylalanines completely abrogated activation of STAT5, and importantly completely impaired induction of a myeloproliferative disease in vivo in a murine transplantation model. ${ }^{31}$ Thus, it is likely that STAT5 signaling is essential for the transforming potential of Flt3-ITD. 


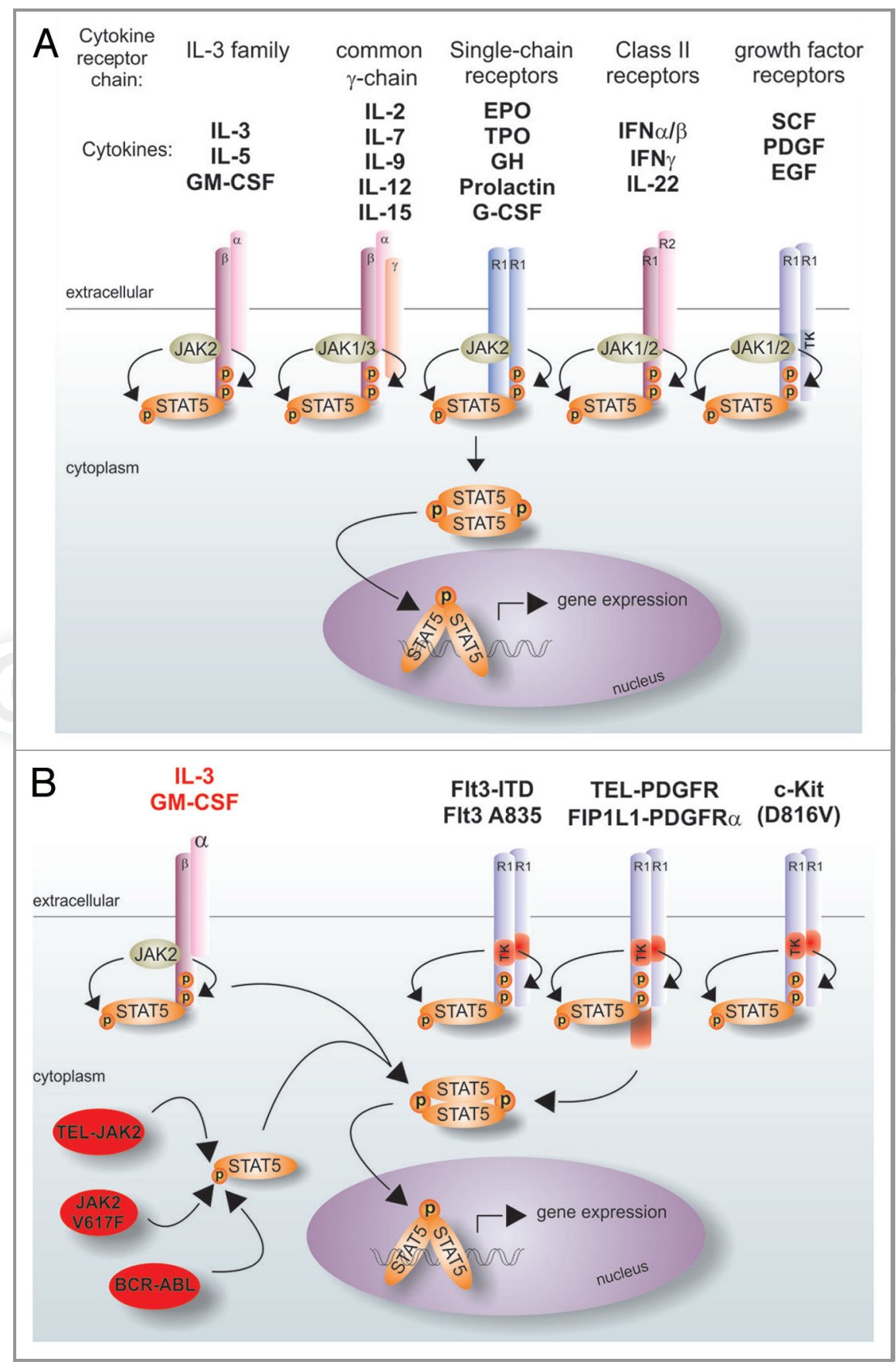

Figure 1. STAT5 signaling in normal and leukemic cells. (A) Normal cytokine-induced STAT5 signaling. (B) Constitutive STAT5 signaling in hematological malignancies.
Although in human cells introduction of Flt3-ITD did not result in a myeloproliferative disease in transplanted NOD-SCID mice, the activated stem cell phenotype imposed on $\mathrm{CB} C \mathrm{CD} 34^{+}$ cells, as revealed by the formation of early cobblestone area forming cells (CAFCs), was impaired by coexpression of a dominant negative STAT5A (Y694F) mutant, ${ }^{32}$ suggesting that also in human cells STAT5 is an important mediator of Flt3ITD-induced signaling. In studies in which STAT5 expression was targeted in primary acute myeloid leukemia (AML) CD34 $4^{+}$ cells using a lentiviral approach, it was observed that long-term expansion and the formation of leukemic CAFCs was strongly impaired by downmodulation of STAT5. ${ }^{33}$ Although the presence of Flt3-ITDs was not the exclusive genetic mutation that induced constitutive STAT5 signaling in the samples that were studied, these data clearly underscore the important role that STAT5 fulfills in longterm expansion and self-renewal of primary AML stem/progenitor cells as well.

In chronic myeloid leukemia (CML) induced by Bcr-Abl, it has been convincingly demonstrated that STAT5 also plays an important role. A number of studies have shown that STAT5 is efficiently activated downstream of Bcr-Abl, ${ }^{59-62}$ and interference with STAT5 activation negatively impacts the survival and proliferation of Bcr-Ablexpressing cells. ${ }^{27,55,63-69}$ Bcr-Abl p210transduced STAT5 ${ }^{\Delta \mathrm{N} / \Delta \mathrm{N}}$ murine bone marrow (BM) cells developed CML with low frequencies, with a delayed onset of disease. ${ }^{55}$ The induction of acute lymphoid leukemia (ALL) was not impaired in these animals. Complete abrogation of STAT5 expression in STAT $5 \mathrm{AB}^{-/-}$mice also impaired lymphoid transformation induced by Bcr-Abl-expressing murine $\mathrm{BM} \cdot{ }^{27,70}$ In primary human CML cells, it was demonstrated that downmodulation of STAT5 expression by RNAi impaired Bcr-Abl-dependent proliferation and also reduced colony formation in methylcellulose. ${ }^{68}$ Inhibition of STAT5 by pimozide reduced colony formation of CML CD $34^{+}$cells, also in tyrosine kinase-resistant patient samples. ${ }^{71}$

In myeloproliferative diseases it has been demonstrated in mouse models that bone marrow (BM)-transduced with TEL-JAK2 no longer induced disease in recipient mice when the oncogene was introduced in a STAT5 ${ }^{\Delta \mathrm{N} / \Delta \mathrm{N}}$ background. ${ }^{40}$ Similarly, MPD induced by TEL-PDGFR $\alpha$ depended on STAT5 activity..$^{50,51}$ Finally, enhanced STAT5 activity has been observed in Polycythemia Vera (PV), caused by the activating JAK2 V617F mutation. ${ }^{72}$ Inhibition of JAK2 kinase activity abrogated the activation of STAT5, which coincided with a suppression of erythropoiesis in vitro and in vivo. ${ }^{73,74}$

The most direct evidence for STAT5 acting as an oncogene arises from murine BM transplantation studies in which constitutively activated STAT5 (S711F) mutants were overexpressed. Lethally irradiated recipients receiving activated STAT5transduced BM died within 6 weeks after transplantation of a multilineage leukemia. ${ }^{75}$ It was demonstrated that a tryptophan residue in the N-terminal region of STAT5 is required for 
Table 1. STAT5 activation in hematological malignancies

$\begin{array}{cccc}\text { Kinase } & \text { Mutation/Translocation } & \text { Disease } & \text { References } \\ \text { Flt3 } & \text { ITD (exon 11-12, 3-400 bp) } & \text { AML } & 31,34-38 \\ & \text { TK point mutations (Asp835) } & \text { AML } & 39 \\ \text { JAK2 } & \text { TEL-JAK2 } & \text { ALL, CML, MPD } & 40 \\ & \text { V617F } & \text { PV, ET, IMF } & 41-44 \\ \text { JAK3 } & \text { A572V, V722I, P132T } & \text { AMKL } & 45 \\ \text { c-Kit } & \text { D816V } & \text { AML } & 46-48 \\ & \text { ITD (exon 11-12) } & \text { Pediatric AML } & 49 \\ \text { PDGFR } & \text { TEL-PDGFR } & \text { CML, MPD } & 50,51 \\ & \text { FIP1L1-PDGFR } \alpha & \text { Chronic Eosinophilic } & 52,53 \\ & & \text { Leukemia } & \\ \text { Abl } & \text { v-ABL (p160) } & \text { CML, BCL } & 54 \\ & \text { BCR-ABL (p210, p185) } & \text { CML } & 27,55 \\ \text { FGFR } & \text { ZNF198-FGFR1 } & \text { MPD } & 56 \\ \text { RAR } \alpha & \text { STAT5b-RAR } \alpha & \text { APL } & 57,58\end{array}$

tetramerization of STAT5 dimers, and tetramer-deficient STAT5 mutants were unable to induce leukemia in mice. ${ }^{75}$ Another activating mutant of STAT5, STAT5A $\left(1^{*} 6\right)$ that contains two point mutations $(\mathrm{H} 299 \mathrm{R} \text { and } \mathrm{S} 711 \mathrm{~F})^{76}$ was earlier shown to induce myeloid hyperproliferation, but not leukemia, in a murine retroviral overexpression model. ${ }^{40}$ This was later confirmed by others, and a fatal MPD was observed by overexpression of these STAT5 mutants, but only when the most primitive CD34- ${ }^{-}$in $^{-}$ $\mathrm{cKit}^{+} \mathrm{Scal}^{+}$(LSK) population was transduced and used for transplantation to irradiated recipients, suggesting that the stem cell, but not a committed progenitor is the target cell for transformation induced by activated STAT5. ${ }^{77}$ Intriguingly, while these examples clearly demonstrate that STAT5 can transform murine hematopoietic stem cells (HSCs), no in vivo STAT5induced transformation has been reported in human cell populations. While enhanced self-renewal and long-term stem cell maintenance can be achieved by introduction of activated STAT5 in human $\mathrm{CD}_{3} 4^{+}$cells, a myeloproliferative disease or leukemia does not occur in non-obese diabetic/severe combined immunodeficiency (NOD-SCID) transplantations models. ${ }^{16}$ It is plausible that the NOD-SCID xenograft model is not suitable to completely recapitulate human disease, or alternatively it is possible that species-specific differences in STAT5 signaling exist. In line with these observations, introduction of Bcr-Abl in murine BM resulted in a rapid and lethal MPD whereby recipients die within 3 weeks after transplantation. Introduction of $\mathrm{Bcr}-\mathrm{Abl}$ in human $\mathrm{CD} 34^{+}$cells does not result in a rapid leukemia or MPD in engrafted NOD-SCID mice, and only after 5 mo progression to an early stage disease was observed in some animals. ${ }^{78,79}$

Collectively, these data indicate that STAT5 is frequently activated in various hematological malignancies, whereby it strongly affects processes such as self-renewal and lineage fate determination. Whether STAT5 target genes in normal and leukemic stem cells are identical, or whether leukemic stem cellspecific STAT5 target genes exist remains to be determined. Also, it will be informative to study how STAT5 might cooperate with additional leukemic oncogenes in a multi-hit approach to model the development of human leukemias.

\section{STAT5 as a Stem Cell Self-Renewal Factor}

Loss-of-function and gain-of-function experiments have revealed critical roles for STAT5 in the hematopoietic stem/progenitor compartment. STAT $5 \mathrm{AB}^{\Delta \mathrm{N} / \Delta \mathrm{N}}$ mice have been used to assess stem cell function in the absence of wt STAT5 signaling. These mice were characterized by normal HSC numbers and stem cells isolated from the bone marrow or fetal liver were capable of engrafting irradiated recipients. ${ }^{80}$ Yet, competitive repopulating capacity of STAT5 AB ${ }^{\Delta N / \Delta N}$ HSCs was severely impaired. ${ }^{80-85}$ The underlying mechanisms are not fully elucidated yet, but it has been observed that the responsiveness of STAT5AB ${ }^{\Delta \mathrm{N} / \Delta \mathrm{N}} \mathrm{HSCs}$ to early-acting cytokines such as IL3 and SCF was reduced, while the sensitivity to 5 -fluoroacil was enhanced. ${ }^{81}$ Loss of protection against apoptosis most likely does not explain the STAT $5 \mathrm{AB}^{\Delta \mathrm{N} / \Delta \mathrm{N}} \mathrm{HSCs}$ phenotypes, as overexpression of $\mathrm{Bcl} 2$ was not sufficient to rescue repopulating defects. ${ }^{84}$ Although homing of STAT $5 A B^{\Delta N / \Delta N}$ BM cells into lethally irradiated recipients was not impaired, ${ }^{83}$ retention in the bone marrow was reduced under non-myeloablative conditions ${ }^{86}$ leaving open the possibility that competition for the niche might play a role. Mice completely devoid of STAT5 display severely impaired hematopoiesis. ${ }^{87}$ More recently, using an Mx1-Cre inducible mouse model, it was shown that conditional deletion of STAT5 results in a loss of stem cell quiescence, associated with reduced survival and gradual loss of the HSC pool. ${ }^{88}$

In order to study STAT5 signaling in human hematopoietic stem/progenitor cells, we have used a lentiviral shRNA approach in cord blood (CB) CD $34^{+}$cells. ${ }^{33}$ Downmodulation of STAT5 to about $30 \%$ of the endogenous levels reduced progenitor frequencies as determined by Colony Forming Cell (CFC) assays in methylcellulose as well as stem cell frequencies as determined by Long-Term Culture-Initiating Cell (LTC-IC) assays in limiting dilution. ${ }^{33}$ This resulted in reduced long-term expansion on MS5 bone marrow stroma upon downmodulation of STAT5 expression, whereby the myeloid and erythroid differentiation were unaffected. Single-cell assays using transduced $\mathrm{CD} 34^{+} /$ $\mathrm{CD}^{-}$cells revealed that cell cycle progression induced by earlyacting cytokines SCF and TPO was impaired by STAT5 downmodulation. ${ }^{33}$

Reversely, activating mutants of STAT5 have been introduced in murine CD34-LSK cells and the effects on stem and progenitor cells were assessed in vitro and in vivo. ${ }^{77}$ Introduction of STAT5A $(1 * 6)$ or STAT5A $(1 * 7)$ mutants resulted in a strong ex vivo expansion of immature CFU-nmEM progenitors, without affecting the symmetry of stem cell divisions as determined in paired-daughter cell assays. ${ }^{77}$ Importantly, long-term repopulating HSCs could be maintained under ex vivo culture conditions as CD34-LSK cells expressing activated STAT5 had a strong competitive repopulating advantage over wild type cells after $7 \mathrm{~d}$ and $10 \mathrm{~d}$ ex vivo culturing in the presence of SCF or SCF and TPO. ${ }^{77}$

Activating mutants of STAT5 have also been introduced in human $\mathrm{CD} 34^{+}$cells. Overexpression of STAT5A $\left(1^{*} 6\right)$ in human $\mathrm{CD} 34^{+}$cord blood cells resulted in enhanced stem cell selfrenewal. ${ }^{16}$ This enhanced self-renewal was only observed in bone marrow stromal cocultures, but not in cytokine-driven liquid 
culture conditions. These data argued that STAT5-induced HSC cell self-renewal depends on the presence of a bone marrow microenvironment, and it was indeed observed that STAT5A ( $\left.1^{*} 6\right)$-expressing CD $34^{+}$cells have a strongly enhanced interaction with bone marrow stromal cells, resulting in the appearance of early CAFCs underneath the stroma within 1 week after plating. These CAFCs contained self-renewal potential as demonstrated by their capacity to give rise to second CAFCs upon harvest and replating onto new stroma, as well as by their capacity to engraft in sublethally irradiated NOD-SCID mice. Upon serial replating, long-term cultures could be established by overexpression of activated STAT5 for over 20 weeks, giving rise to new CAFCs upon each replating as well as to progeny in suspension. Hematopoietic progenitors could be maintained long-term in these culture conditions and the suspension cells retained an immature blast-like morphology. ${ }^{16}$

When STAT5A $\left(1^{*} 6\right)$ mutants were expressed in murine embryonic stem (ES) cells, the generation of hematopoietic stem cells was greatly facilitated as studied on OP9 bone marrow stromal cells. ${ }^{17}$ The generation of hematopoietic CAFCs was strongly enhanced by activated STAT5. Importantly, these CAFCs could be serially passaged onto new OP9 stroma, giving rise to second and third CAFCs that were able to sustain longterm hematopoiesis and generate high numbers hematopoietic progenitors, indicative of HSC self-renewal in vitro. Also, the CAFCs generated by activation of STAT5 could engraft sublethally irradiated NOD-SCID mice, indicating that STAT5 facilitates the generation of ES-derived HSCs that can contribute to hematopoiesis in vivo as well. ${ }^{17}$

\section{Mechanisms Involved in STAT5-Induced HSC Self-Renewal}

Although various STAT5 target genes have been identified, the mechanisms by which STAT5 acts on HSCs remain to be elucidated. Using cell lines or heterogeneous stem/progenitor cell populations, enhanced cell growth is one of the most dominant phenotypes that is frequently observed in various studies, and several genes that are regulated by STAT5 associate with cell proliferation and cell cycle progression, including Cyclin D1, Pim1 and c-Myc. ${ }^{16,89-91}$ CyclinD1 $^{-/-} \mathrm{D} 2^{-/-}$mice exhibit defects in the expansion of hematopoietic stem/progenitor cells. ${ }^{92}$ Pim serine/threonine kinases act as mediators of cytokine-induced cell growth ${ }^{93}$ by promoting acceleration of cell-cycle progression both at the G1/S and G2/M transitions by phosphorylating and activating the phosphatases $\mathrm{Cdc} 25 \mathrm{~A}$ and $\mathrm{Cdc} 25 \mathrm{C}$, respectively. ${ }^{94,95} \mathrm{c}$-Myc controls the balance between self-renewal and differentiation of HSCs. ${ }^{96,97}$ However, when more purified stem cell populations were studied using a conditional deletion Mx1Cre model it was observed that STAT5 was required to maintain HSC quiescence. Upon STAT5 deletion a decrease in the percentage of cells in G0 within the long-term and short-term HSC compartments was observed, coinciding with a decrease in expression of quiescence-associated genes such as p57 and Tie2. ${ }^{88}$ Loss of STAT5 also coincided with an increase in AnnexinV ${ }^{+}$ CD34-LSK cells. ${ }^{88}$ In erythroid cells, it has been convincingly demonstrated that STAT5 contributes to cell survival by upregulating the anti-apoptosis gene $\mathrm{Bcl}-\mathrm{X}_{\mathrm{L}} \cdot{ }^{13,14}$ Survival of Flt3-ITD ${ }^{+}$AML cells has been shown to depend on STAT5mediated expression of $\mathrm{Mcl} 1 .{ }^{98} \mathrm{Also}, \mathrm{Bcl} 2$ can be upregulated by STAT5 and is required to prevent apoptosis during terminal differentiation of myeloid cells. ${ }^{23}$ Whether prevention of apoptosis contributes to STAT5-induced HSC self-renewal is currently unclear, but $\mathrm{Bcl} 2$ overexpression was not sufficient to rescue the repopulation defects of STAT $5 \mathrm{AB}^{\Delta \mathrm{N} / \Delta \mathrm{N}} \mathrm{HSCs},{ }^{84}$ suggesting that protection against apoptosis is not the main role of STAT5 signaling in HSCs. In our co-cultures, despite strong reductions in LTC-IC and CFC frequencies, we also did not detect an increased rate of apoptosis in STAT5 RNAi-transduced CD34 $4^{+} \mathrm{CB}$ cells, and no decreased expression of the $\mathrm{Bcl}-\mathrm{X}_{\mathrm{L}}$ gene was observed. ${ }^{33}$ The basic helix-loop-helix transcriptional inhibitor ID1 is also upregulated by STAT5, ${ }^{99}$ and ID1-deficient HSCs fail to selfrenew, leading to low steady-state HSC numbers and premature HSC exhaustion. ${ }^{100}$ Little evidence exists that STAT5 affects the expression of other known HSC self-renewal regulators such as Bmil or HoxB4. Recently, we observed that STAT5 binds to and activates the promoter of Hypoxia Induced Factor $2 \alpha(\mathrm{Hif} 2 \alpha)$ in human $\mathrm{CD}^{2} 4^{+} / \mathrm{CD} 38^{-}$HSCs. ${ }^{101}$ Functional studies indicated that STAT5-induced long-term expansion and elevated LTC-IC and $\mathrm{CFC}$ frequencies were reduced upon downmodulation of Hif $2 \alpha{ }^{101}$ Glucose uptake was enhanced in cells expression activated STAT5, coinciding with a Hif $2 \alpha$-dependent upregulation glucose metabolism genes, suggesting that pathways normally active under hypoxia might be utilized by STAT5 under normoxic conditions as well to maintain stem cell properties.

The phenotype imposed on cells by STAT 5 might well depend on the actual level of STAT5 activity that is induced. Using a 4-hydroxytamoxifen inducible system that allowed titration of STAT5 activity in human stem and progenitor cells we have demonstrated that the stem cell maintenance properties require intermediate STAT5 activation. ${ }^{102}$ On the other hand, high STAT5 activation levels resulted in erythroid differentiation at the expense of HSC self-renewal. ${ }^{102} \mathrm{C} / \mathrm{ebp} \alpha$ levels were reduced upon STAT5 activation, which reached maximum reduction levels at intermediate STAT5 activation. In line with these observations, in mice $\mathrm{C} / \mathrm{ebp} \alpha$ deficiency resulted in hyperproliferation of hematopoietic progenitor cells and enhancement of hematopoietic stem cell repopulating capacity and self-renewal. ${ }^{103,104}$ Reintroduction of C/ebp $\alpha$ in STAT5A(1*6)-transduced human $\mathrm{CD} 34^{+}$cells was sufficient to impair HSC self-renewal capacity. ${ }^{105}$ The mechanisms by which STAT5 affects C/ebp $\alpha$ expression levels are still under investigation, but these observations leave open the possibility that enhanced HSC self-renewal might in part be explained by reduction in C/ebp $\alpha$ expression levels.

It is remarkable that the effects of STAT5 on HSC self-renewal are confined to intermediate STAT5 activation levels. ${ }^{102}$ This dosage effect of STAT5 on self-renewal is consistent with the observed constitutive activation of STAT5 in AML samples, which is typically lower then cytokine-induced STAT5 activation. ${ }^{37,106,107}$ Such a dosage effect of transcription factors is at present not well understood, but besides STAT5 this has also been observed for the myeloid transcription factor Pu.1, which 
at $20 \%$ expression gives rise to self-renewing murine myeloid leukemias, whereas $50 \%$ or $100 \%$ reduction in expression do not have such a dramatic effect. ${ }^{108,109}$ Recently, also for Wnt signaling it was demonstrated that intermediate activation levels enhance self-renewal of HSCs. ${ }^{110}$ Collectively, these examples clearly underscore the role of transcription factor dosage in regulating HSC self-renewal.

\section{Cell Type-Specific STAT5 Signaling: Differential Role of STAT5 in Hematopoietic Stem and Progenitor Cells?}

The observation that STAT5 drives cell cycle progression in various cell types and anti-apoptosis in others, while STAT5 is also required to maintain quiescence of hematopoietic stem cells, suggests that the cell-biological consequences of STAT5 signaling might be highly cell type-specific. We have addressed this issue by introducing a 4-hydroxytamoxifen (4OHT)-inducible STAT5ER fusion in human stem and progenitor cells. ${ }^{101}$ Activation of STAT5 specifically in HSC, common myeloid (CMP), granulocyte-macrophage (GMP) or megakaryocyte-erythroid progenitor (MEP) populations resulted in rather distinct phenotypes. Longterm self-renewal and enhanced cobblestone formation could only be imposed on HSCs, but not on committed progenitor subpopulations. Erythroid differentiation could be induced in HSC, CMP and MEP populations, but not in GMPs. Gene expression profiling revealed that rather distinct gene expression profiles were induced in HSC as compared with more committed progenitor subpopulations. For instance, Tubb1, Hif2 $\alpha$, Sod2, IL8 and also the cell cycle inhibitor Cdkn1a/p21 were particularly upregulated in HSCs but not in committed progenitors (Fig. 2). In contrast, Osm, Pim1 and the negative feedback regulators CISH and Socs 2 were upregulated both in HSCs and MPPs. The underlying mechanisms are currently unclear, but a number of possibilities might be hypothesized. First, it has been shown that several cofactors such as p300/Cbp, but also interactions with other transcription factors such as Foxo3a, can modulate and fine-tune the STAT5 response. ${ }^{111-113}$ Cell type-specific interaction with such cofactors would then dictate a cell type-specific STAT5 activation pattern of target genes. Seen from this perspective, the modulation of STAT5 signaling by $\mathrm{p} 300 / \mathrm{Cbp}$ could add to a stem vs. progenitor-specific component of STAT5. It has been observed that, unlike p300, Cbp is essential for HSC selfrenewal maintenance, while p300 is suggested to play a role in differentiation. ${ }^{114-116}$ Interaction of various transcription factors with $\mathrm{p} 300 / \mathrm{Cbp}$ is facilitated by the $\mathrm{p} 300 / \mathrm{Cbp}$ interacting protein

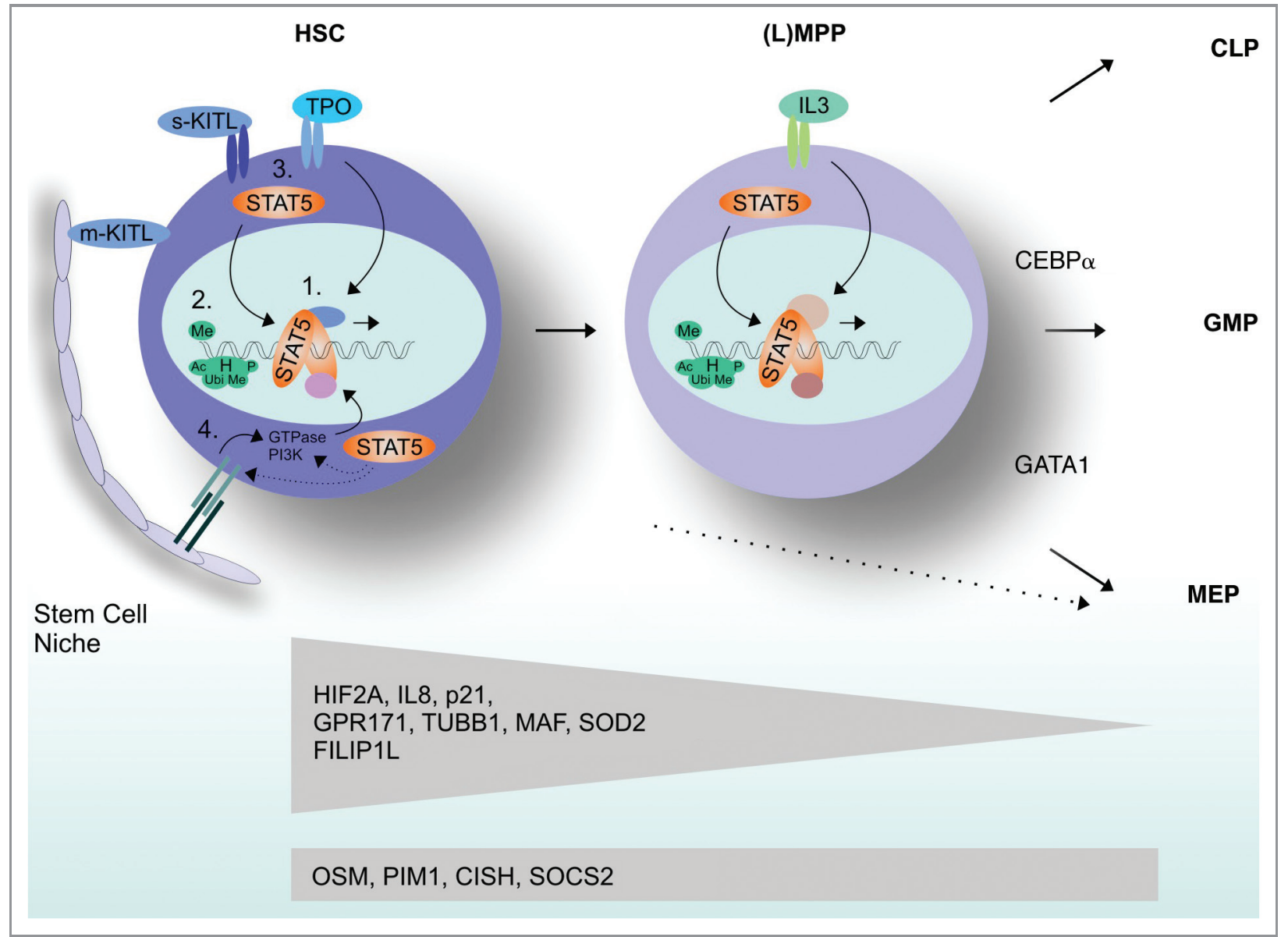

Figure 2. Cell type-specific STAT5 signaling in hematopoietic stem and progenitor cells. (1) Expression/activation of cofactors: complex composition. (2) Epigenetic factors that influence STAT5 DNA binding. (3) Expression of receptors and ligands. (4) Niche interactions. 
Cited 2 which has been shown to be a target gene of STAT5 ${ }^{113}$ and has differential expression and functions in hematopoietic stem vs. progenitor cells ${ }^{117}$ (and our own observations). In part, such interactions can be mediated by posttranslational modifications such as serine phosphorylation or glycosylation of STAT5. ${ }^{112}$ Thus, besides the induction of STAT5 tyrosine phosphorylation required for dimerization, nuclear translocation and DNA binding, the simultaneous activation of pathways that mediate STAT5 serine phosphorylation or glycosylation would be required.

Furthermore, the epigenetic status of the cell might play an important role. Hypermethylation of specific promoters or polycomb-mediated condensation of chromatin might prevent STAT5 association with regulatory promoter elements and thus transactivation of certain genes. Clearly, such differences in epigenetic status and cofactor expression might also be dictated by different responses to extracellular stimuli. Thus, the repertoire of specific cytokine and growth factor receptors that is expressed on a cell, as well as direct interactions between hematopoietic stem cells and their bone marrow niche, might ultimately determine the specific STAT5 response (Fig. 2).

Single cell tyrosine phospho-STAT5 analysis revealed that within the normal hematopoietic stem cell and progenitor compartment highly distinct cytokine-induced STAT5 activation patterns are observed. ${ }^{6}$ Also in primary AML patient samples, rather heterogeneous responses toward a series of cytokines were observed, not directly linked to whether or not the cognate receptor was expressesed. ${ }^{6}$ There was clear heterogeneity between different patient samples, but also different responses could be observed within distinct cellular compartments within a single patient. ${ }^{6,118}$ For instance, in some patient samples strong IL3 and GM-CSF responses were observed, but only in the CD34subpopulation, while in other cases strong TPO responses were observed within $\mathrm{CD} 34^{+} / \mathrm{CD} 38^{-}$and $\mathrm{CD} 34^{+} / \mathrm{CD} 38^{+}$compartments. These observations clearly indicate that strong differences exist in how cytokine and growth factor signals are mediated within a certain cell type, both normal as well as leukemic.

Although elucidation of molecular mechanisms by which cell type specific STAT5 signaling is orchestrated needs further studies, cell type-specific STAT5 target genes clearly do exist. The observation that p21 is upregulated by STAT5, particularly in HSCs, is remarkable (our unpublished observations and ref. 101). It will be interesting to analyze whether the enhanced long-term self-renewal that is observed upon activation of STAT5 in hematopoietic stem cells ${ }^{16}$ involves improved stem cell maintenance by keeping the HSCs pool in a relatively quiescent state via upregulation of p21. Knockout studies in mice have indicated that $\mathrm{p} 21$ is required during stress hematopoiesis, ${ }^{119}$ and although p21 was also initially downregulated in STAT5 depleted LSK cells, this downmodulation was not maintained. ${ }^{88}$ On the other hand, in murine embryonic fibroblasts it has also been shown that STAT5 can negatively regulate cell cycle progression through activation of p21. ${ }^{120}$ Inhibition of JAK2/STAT5 signaling by the specific Jak2 inhibitor AZ960 stimulated cell cycling in CD $34^{+} /$ $\mathrm{CD}^{-}$cells in conjunction with downregulation of $\mathrm{p} 21 .{ }^{118}$ Further, activation of $\mathrm{p} 21$ has been shown to be critical in preventing excess DNA-damage accumulation and functional exhaustion of leukemic stem cells, ${ }^{121}$ and it will be interesting to further reveal its role downstream of STAT5 in HSCs.

Furthermore, HIF2 $\alpha$ was upregulated in HSCs and CMPs by STAT5, but not in MEPs and GMPs. ${ }^{101}$ Under normoxic conditions, proline residues of Hypoxia-Induced Factor 2 are hydroxylated resulting in a reduction in protein levels via VHLmediated proteasomal degradation. Under hypoxic conditions, such as in the presumed endosteal quiescent stem cell niche, Hifs are stabilized and act as transcription factors. ${ }^{122}$ It is currently unknown whether and which Hif-induced target genes are essential to maintain stemness of normal HSCs, but it was recently shown that in $\mathrm{Hif1}^{-1-}$ mice HSCs numbers decrease during stress which was associated with a loss of HSC quiescence. ${ }^{123}$ Another report indicated that HSCs in the quiescence niche utilize glycolysis for their energy demands, which depended on a Meis1-induced Hif $1 \alpha$ signaling network. ${ }^{124}$ Whether Hifl $\alpha$ and $\mathrm{Hif} 2 \alpha$ display similar or distinct functions in HSCs remains to be established.

Our understanding of the mechanisms that determine whether, where and when a stem cell will self-renew or differentiate is still limited, but recent advances have indicated that the stem cell microenvironment provides essential cues that direct these cell fate decisions. ${ }^{125-128}$ It is remarkable that STAT5induced long-term self-renewal is typically observed when cells are cultured in direct contact with stromal cells, ${ }^{16}$ in contrast to, e.g., Bmil-induced self-renewal, which occurred in a more microenvironment-independent manner. ${ }^{129}$ Thus, altered interactions with the stem cells niche might also underlie the enhanced self-renewal properties imposed on HSCs by activated STAT5. Although the mechanisms by which the interaction with the microenvironment of STAT5A $\left(1^{*} 6\right)$-expressing CD $34^{+}$cells are still unclear, our ongoing studies in which gene-expression profiling was performed in HSCs and progenitor subsets revealed that the list of STAT5-targets is significantly enriched for membrane (associated) proteins. ${ }^{102}$ One of the STAT5 targets that has been identified is $\mathrm{MUC1}^{130}$ which is a (proto)oncogene involved in adhesion and transendothelial migration, and has been associated with initiation of various intracellular signal transduction pathways including $\beta$-catenin, p53 and NFKB pathways. ${ }^{131-136}$ Also, MUC1 has been shown to mediate an oscillatory calcium signal upon binding to ICAM1. ${ }^{137}$ Within the endosteal region of the bone marrow where stem cells are thought to reside, $\mathrm{Ca}^{2+}$ levels are high, and HSC retention within the niche depends on the Calcium-Sensing receptor (CaR). ${ }^{138}$ Thus, STAT5 might exert its phenotype, at least in part, by influencing interactions between HSCs and their niche.

\section{Conclusions and Future Perspectives}

In both murine and human model systems it has been convincingly shown that STAT5 fulfills an important role in hematopoietic stem cell self-renewal. Although the precise mechanisms by which HSC self-renewal is orchestrated by STAT5 remain elusive to date, an increasing number of STAT5 target genes have been identified that are currently under investigation. In myeloproliferative diseases and leukemias, a 
number of oncogenes have been identified that are capable of inducing STAT5 activity, and accumulating evidence has indicated that STAT5 participates in self-renewal of leukemic stem cells as well. Thus, it appears likely that STAT5 will become an important diagnostic marker in the near future, and specific targeting of STAT5 should be focus of therapeutical intervention strategies to improve treatment of hematological malignancies.

\section{References}

1. Bunting KD. STAT5 signaling in normal and pathologic hematopoiesis. Front Biosci 2007; 12:2807-20; PMID: 17485261; http://dx.doi.org/10.2741/2274

2. Paukku K, Silvennoinen O. STATs as critical mediators of signal transduction and transcription: lessons learned from STAT5. Cytokine Growth Factor Rev 2004; 15:435-55; PMID:15561601; http://dx. doi.org/10.1016/j.cytogfr.2004.09.001

3. Schindler C, Darnell JE, Jr. Transcriptional responses to polypeptide ligands: the JAK-STAT pathway. Annu Rev Biochem 1995; 64:621-52; PMID:75744495; http:// dx.doi.org/10.1146/annurev.bi.64.070195.003201

4. Ihle JN. The Stat family in cytokine signaling. Curr Opin Cell Biol 2001; 13:211-7; PMID:11248555; http://dx.doi.org/10.1016/S0955-0674(00)00199-X

5. Hennighausen L, Robinson GW. Interpretation of cytokine signaling through the transcription factors STAT5A and STAT5B. Genes Dev 2008; 22:711-21; PMID: 18347089; http://dx.doi.org/10.1101/gad.1643908

6. Han L, Wierenga AT, Rozenveld-Geugien M, van de Lande K, Vellenga E, Schuringa JJ. Single-cell STAT5 signal transduction profiling in normal and leukemic stem and progenitor cell populations reveals highly distinct cytokine responses. PLoS One 2009; 4:e7989; PMID:19956772; http://dx.doi.org/10.1371/journal pone. 0007989

7. Ryan JJ, Huang H, McReynolds LJ, Shelburne C, Hu-Li J, Huff TF, et al. Stem cell factor activates STAT-5 DNA binding in IL-3-derived bone marrow mast cells. Exp Hematol 1997; 25:357-62; PMID: 9131012

8. Pallard C, Gouilleux F, Bénit L, Cocault L, Souyri M, Levy D, et al. Thrombopoietin activates a STAT5-like factor in hematopoietic cells. EMBO J 1995; 14:284756; PMID:7796811

9. Feugier P, Li N, Jo DY, Shieh JH, MacKenzie KL, Lesesve JF, et al. Osteopetrotic mouse stroma with thrombopoietin, c-kit ligand, and flk-2 ligand supports long-term mobilized CD34+ hematopoiesis in vitro. Stem Cells Dev 2005; 14:505-16; PMID:16305336; http://dx.doi.org/10.1089/scd.2005.14.505

10. Seita J, Ema H, Ooehara J, Yamazaki S, Tadokoro Y, Yamasaki A, et al. Lnk negatively regulates self-renewal of hematopoietic stem cells by modifying thrombopoietin-mediated signal transduction. Proc Natl Acad Sci U S A 2007; 104:2349-54; PMID:17284614; http://dx.doi.org/10.1073/pnas.0606238104

11. Pallard C, Gouilleux F, Charon M, Groner B, Gisselbrecht S, Dusanter-Fourt I. Interleukin-3, erythropoietin, and prolactin activate a STAT5-like factor in lymphoid cells. J Biol Chem 1995; 270:15942-5; PMID:7608147; http://dx.doi.org/10.1074/jbc.270 27.15942

12. Nosaka T, Kawashima T, Misawa K, Ikuta K, Mui AL, Kitamura T. STAT5 as a molecular regulator of proliferation, differentiation and apoptosis in hematopoietic cells. EMBO J 1999; 18:4754-65; PMID: 10469654; http://dx.doi.org/10.1093/emboj/18.17.4754

13. Socolovsky M, Fallon AE, Wang S, Brugnara C, Lodish HF. Fetal anemia and apoptosis of red cell progenitors in Stat5a-/-5b-/- mice: a direct role for Stat5 in Bcl-X(L) induction. Cell 1999; 98:181-91; PMID:10428030; http://dx.doi.org/10.1016/S00928674(00)81013-2

14. Socolovsky M, Nam H, Fleming MD, Haase VH, Brugnara C, Lodish HF. Ineffective erythropoiesis in Stat $5 \mathrm{a}(-/-) 5 \mathrm{~b}(-/-)$ mice due to decreased survival of early erythroblasts. Blood 2001; 98:3261-73; PMID: 11719363; http://dx.doi.org/10.1182/blood.V98.12. 3261
15. Garçon L, Rivat C, James C, Lacout C, CamaraClayette V, Ugo V, et al. Constitutive activation of STAT5 and Bcl-xL overexpression can induce endogenous erythroid colony formation in human primary cells. Blood 2006; 108:1551-4; PMID:16684963; http://dx.doi.org/10.1182/blood-2005-10-009514

16. Schuringa JJ, Chung KY, Morrone G, Moore MA Constitutive activation of STAT5A promotes human hematopoietic stem cell self-renewal and erythroid differentiation. J Exp Med 2004; 200:623-35; PMID: 15353555; http://dx.doi.org/10.1084/jem.20041024

17. Schuringa JJ, Wu K, Morrone G, Moore MA Enforced activation of STAT5A facilitates the generation of embryonic stem-derived hematopoietic stem cells that contribute to hematopoiesis in vivo. Stem Cells 2004; 22:1191-204; PMID:15579639; http:// dx.doi.org/10.1634/stemcells.2004-0033

18. Grebien F, Kerenyi MA, Kovacic B, Kolbe T, Becker $\mathrm{V}$, Dolznig $\mathrm{H}$, et al. Stat 5 activation enables erythropoiesis in the absence of EpoR and Jak2. Blood 2008; 111:4511-22; PMID:18239084; http:// dx.doi.org/10.1182/blood-2007-07-102848

19. Li G, Wang Z, Zhang Y, Kang Z, Haviernikova E, Cui $\mathrm{Y}$, et al. STAT5 requires the $\mathrm{N}$-domain to maintain hematopoietic stem cell repopulating function and appropriate lymphoid-myeloid lineage output. Exp Hematol 2007; 35:1684-94; PMID:17976521; http:// dx.doi.org/10.1016/j.exphem.2007.08.026

20. Mui AL, Wakao H, O'Farrell AM, Harada N Miyajima A. Interleukin-3, granulocyte-macrophage colony stimulating factor and interleukin-5 transduce signals through two STAT5 homologs. EMBO J 1995; 14:1166-75; PMID:7720707

21. Azam M, Erdjument-Bromage H, Kreider BL, Xia M Quelle F, Basu R, et al. Interleukin-3 signals through multiple isoforms of Stat5. EMBO J 1995; 14:140211; PMID:7537213

22. Coffer PJ, Koenderman L, de Groot RP. The role of STATs in myeloid differentiation and leukemia. Oncogene 2000; 19:2511-22; PMID:10851050; http://dx.doi.org/10.1038/sj.onc.1203479

23. Kieslinger M, Woldman I, Moriggl R, Hofmann J, Marine JC, Ihle JN, et al. Antiapoptotic activity of Stat5 required during terminal stages of myeloid differentiation. Genes Dev 2000; 14:232-44; PMID:10652277

24. Xiao W, Hong H, Kawakami Y, Lowell CA, Kawakami T. Regulation of myeloproliferation and M2 macrophage programming in mice by Lyn/Hck, SHIP, and Stat5. J Clin Invest 2008; 118:924-34; PMID:18246197

25. Kimura A, Rieger MA, Simone JM, Chen W, Wickre $\mathrm{MC}$, Zhu BM, et al. The transcription factors STAT5A/B regulate GM-CSF-mediated granulopoiesis. Blood 2009; 114:4721-8; PMID:19779039; http://dx. doi.org/10.1182/blood-2009-04-216390

26. Buitenhuis M, Baltus B, Lammers JW, Coffer PJ, Koenderman L. Signal transducer and activator of transcription 5a (STAT5a) is required for eosinophil differentiation of human cord blood-derived CD34+ cells. Blood 2003; 101:134-42; PMID:12393707; http://dx. doi.org/10.1182/blood-2002-03-0740

27. Hoelbl A, Kovacic B, Kerenyi MA, Simma O, Warsch W, Cui Y, et al. Clarifying the role of Stat 5 in lymphoid development and Abelson-induced transformation. Blood 2006; 107:4898-906; PMID:16493008; http:// dx.doi.org/10.1182/blood-2005-09-3596

28. Moriggl R, Sexl V, Piekorz R, Topham D, Ihle JN. Stat 5 activation is uniquely associated with cytokine signaling in peripheral T cells. Immunity 1999; 11 225-30; PMID:10485657; http://dx.doi.org/10.1016/ S1074-7613(00)80097-7
29. Moriggl R, Topham DJ, Teglund S, Sexl V, McKay C, Wang D, et al. Stat5 is required for IL-2-induced cell cycle progression of peripheral $\mathrm{T}$ cells. Immunity 1999; 10:249-59; PMID:10072077; http://dx.doi.org/ 10.1016/S1074-7613(00)80025-4

30. Dai X, Chen Y, Di L, Podd A, Li G, Bunting KD, et al. Stat 5 is essential for early B cell development but not for B cell maturation and function. J Immunol 2007; 179:1068-79; PMID:17617599

31. Rocnik JL, Okabe R, Yu JC, Lee BH, Giese N, Schenkein DP, et al. Roles of tyrosine 589 and 591 in STAT5 activation and transformation mediated by FLT3-ITD. Blood 2006; 108:1339-45; PMID:16627759; http://dx. doi.org/10.1182/blood-2005-11-011429

32. Chung KY, Morrone G, Schuringa JJ, Wong B, Dorn DC, Moore MA. Enforced expression of an Flt3 internal (andem duplication in human CD34+ cells confers properties of self-renewal and enhanced erythropoiesis. Blood 2005; 105:77-84; PMID:15242879; http://dx. doi.org/10.1182/blood-2003-12-4445

33. Schepers H, van Gosliga D, Wierenga AT, Eggen BJ Schuringa JJ, Vellenga E. STAT5 is required for longterm maintenance of normal and leukemic human stem/progenitor cells. Blood 2007; 110:2880-8; PMID 17630355; http://dx.doi.org/10.1182/blood-2006-08039073

34. Choudhary C, Brandts C, Schwable J, Tickenbrock L, Sargin B, Ueker A, et al. Activation mechanisms of STAT5 by oncogenic Flt3-ITD. Blood 2007; 110: 370-4; PMID:17356133; http://dx.doi.org/10.1182/ blood-2006-05-024018

35. Choudhary C, Schwäble J, Brandts C, Tickenbrock L, Sargin B, Kindler T, et al. AML-associated Flt3 kinase domain mutations show signal transduction differences compared with Flt3 ITD mutations. Blood 2005; 106:265-73; PMID:15769897; http://dx.doi.org/10. 1182/blood-2004-07-2942

36. Kiyoi $H$, Ohno $R$, Ueda $R$, Saito $H$, Naoe $T$. Mechanism of constitutive activation of FLT3 with internal tandem duplication in the juxtamembrane domain. Oncogene 2002; 21:2555-63; PMID: 11971190; http://dx.doi.org/10.1038/sj.onc.1205332

37. Birkenkamp KU, Geugien M, Lemmink HH, Kruije W, Vellenga E. Regulation of constitutive STAT5 phosphorylation in acute myeloid leukemia blasts. Leukemia 2001; 15:1923-31; PMID:11753614; http://dx.doi.org/10.1038/sj.leu.2402317

38. Mizuki M, Fenski R, Halfter H, Matsumura I, Schmidt R, Müller C, et al. Flt3 mutations from patients with acute myeloid leukemia induce transformation of $32 \mathrm{D}$ cells mediated by the Ras and STAT5 pathways. Blood 2000; 96:3907-14; PMID: 11090077

39. Abu-Duhier FM, Goodeve AC, Wilson GA, Care RS, Peake IR, Reilly JT. Identification of novel FLT-3 Asp835 mutations in adult acute myeloid leukaemia. Br J Haematol 2001; 113:983-8; PMID:11442493; http://dx.doi.org/10.1046/j.1365-2141.2001.02850.x

40. Schwaller J, Parganas E, Wang D, Cain D, Aster JC, Williams IR, et al. Stat 5 is essential for the myelo- and lymphoproliferative disease induced by TEL/JAK2 Mol Cell 2000; 6:693-704; PMID:11030348; http:// dx.doi.org/10.1016/S1097-2765(00)00067-8

41. Baxter EJ, Scott LM, Campbell PJ, East C, Fourouclas $\mathrm{N}$, Swanton S, et al \& Cancer Genome Project. Acquired mutation of the tyrosine kinase JAK2 in human myeloproliferative disorders. Lancet 2005; 365:1054-61; PMID:15781101 
42. James C, Ugo V, Le Couédic JP, Staerk J, Delhommeau F, Lacout $\mathrm{C}$, et al. A unique clonal JAK2 mutation leading to constitutive signalling causes polycythaemia vera. Nature 2005; 434:1144-8; PMID: 15793561; http://dx.doi.org/10.1038/nature03546

43. Kralovics R, Passamonti F, Buser AS, Teo SS, Tiedt R, Passweg JR, et al. A gain-of-function mutation of JAK2 in myeloproliferative disorders. N Engl J Med 2005; 352:1779-90; PMID:15858187; http://dx.doi.org/10. 1056/NEJMoa051113

44. Levine RL, Wadleigh M, Cools J, Ebert BL, Wernig G, Huntly BJ, et al. Activating mutation in the tyrosine kinase JAK2 in polycythemia vera, essential thrombocythemia, and myeloid metaplasia with myelofibrosis. Cancer Cell 2005; 7:387-97; PMID:15837627; http:// dx.doi.org/10.1016/j.ccr.2005.03.023

45. Walters DK, Mercher T, Gu TL, O'Hare T, Tyner JW, Loriaux M, et al. Activating alleles of JAK3 in acute megakaryoblastic leukemia. Cancer Cell 2006; 10:65-75; PMID:16843266; http://dx.doi.org/10.1016/ j.ccr.2006.06.002

46. Brizzi MF, Dentelli P, Rosso A, Yarden Y, Pegoraro L. STAT protein recruitment and activation in c-Kit deletion mutants. J Biol Chem 1999; 274:16965-72; PMID:10358045; http://dx.doi.org/10.1074/jbc.274. 24.16965

47. Ikeda H, Kanakura Y, Tamaki T, Kuriu A, Kitayama $\mathrm{H}$, Ishikawa J, et al. Expression and functional role of the proto-oncogene c-kit in acute myeloblastic leukemia cells. Blood 1991; 78:2962-8; PMID:1720040

48. Beghini A, Larizza L, Cairoli R, Morra E. c-kit activating mutations and mast cell proliferation in human leukemia. Blood 1998; 92:701-2; PMID:9657776

49. Corbacioglu S, Kilic M, Westhoff MA, Reinhardt D, Fulda S, Debatin KM. Newly identified c-KIT receptor tyrosine kinase ITD in childhood AML induces ligand-independent growth and is responsive to a synergistic effect of imatinib and rapamycin. Blood 2006; 108:3504-13; PMID:16840725; http://dx.doi. org/10.1182/blood-2006-05-021691

50. Cain JA, Xiang Z, O'Neal J, Kreisel F, Colson A, Luo $\mathrm{H}$, et al. Myeloproliferative disease induced by TEL-PDGFRB displays dynamic range sensitivity to Stat5 gene dosage. Blood 2007; 109:3906-14; PMID: 17218386; http://dx.doi.org/10.1182/blood-2006-07036335

51. Sternberg DW, Tomasson MH, Carroll M, Curley DP, Barker G, Caprio M, et al. The TEL/PDGFbetaR fusion in chronic myelomonocytic leukemia signals through STAT5-dependent and STAT5-independent pathways. Blood 2001; 98:3390-7; PMID:11719379; http://dx.doi.org/10.1182/blood.V98.12.3390

52. Buitenhuis $\mathrm{M}$, Verhagen LP, Cools J, Coffer PJ. Molecular mechanisms underlying FIP1L1-PDGFRAmediated myeloproliferation. Cancer Res 2007; 67: 3759-66; PMID:17440089; http://dx.doi.org/10.1158/ 0008-5472.CAN-06-4183

53. Cools J, Stover EH, Gilliland DG. Detection of the FIP1L1-PDGFRA fusion in idiopathic hypereosinophilic syndrome and chronic eosinophilic leukemia. Methods Mol Med 2006; 125:177-87; PMID: 16502585

54. Danial NN, Pernis A, Rothman PB. Jak-STAT signaling induced by the v-abl oncogene. Science 1995; 269:1875-7; PMID:7569929; http://dx.doi.org/ $10.1126 /$ science. 7569929

55. Ye D, Wolff N, Li L, Zhang S, Ilaria RL, Jr. STAT5 signaling is required for the efficient induction and maintenance of CML in mice. Blood 2006; 107: 4917-25; PMID:16522816; http://dx.doi.org/10.1182/ blood-2005-10-4110

56. Heath C, Cross NC. Critical role of STAT5 activation in transformation mediated by ZNF198-FGFR1. J Biol Chem 2004; 279:6666-73; PMID:14660670; http://dx.doi.org/10.1074/jbc.M308743200
57. Dong S, Tweardy DJ. Interactions of STAT5bRARalpha, a novel acute promyelocytic leukemia fusion protein, with retinoic acid receptor and STAT3 signaling pathways. Blood 2002; 99:2637-46; PMID:11929748; http://dx.doi.org/10.1182/blood.V99.8.2637

58. Arnould C, Philippe C, Bourdon V, Gr goire MJ, Berger $\mathrm{R}$, Jonveaux P. The signal transducer and activator of transcription STAT5b gene is a new partner of retinoic acid receptor alpha in acute promyelocytic-like leukaemia. Hum Mol Genet 1999; 8:1741-9; PMID 10441338; http://dx.doi.org/10.1093/hmg/8.9.1741

59. Carlesso N, Frank DA, Griffin JD. Tyrosyl phosphorylation and DNA binding activity of signa transducers and activators of transcription (STAT) proteins in hematopoietic cell lines transformed by Bcr/Abl. J Exp Med 1996; 183:811-20; PMID 8642285; http://dx.doi.org/10.1084/jem.183.3.811

60. Ilaria RL, Jr., Van Etten RA. P210 and P190(BCR/ $\mathrm{ABL}$ ) induce the tyrosine phosphorylation and DNA binding activity of multiple specific STAT family members. J Biol Chem 1996; 271:31704-10; PMID 8940193; http://dx.doi.org/10.1074/jbc.271.49.31704

61. Frank DA, Varticovski L. BCR/abl leads to the constitutive activation of Stat proteins, and shares an epitope with tyrosine phosphorylated Stats. Leukemia 1996; 10:1724-30; PMID:8892675

62. Shuai K, Halpern J, ten Hoeve J, Rao X, Sawyers CL. Constitutive activation of STAT5 by the BCR-ABL oncogene in chronic myelogenous leukemia. Oncogene 1996; 13:247-54; PMID:8710363

63. Nieborowska-Skorska M, Wasik MA, Slupianek A Salomoni P, Kitamura T, Calabretta B, et al. Signa transducer and activator of transcription (STAT) 5 activation by BCR/ABL is dependent on intact Src homology (SH) 3 and $\mathrm{SH} 2$ domains of BCR/ABL and is required for leukemogenesis. J Exp Med 1999; 189:1229-42; PMID:10209040; http://dx.doi.org/10. 1084/jem.189.8.1229

64. Horita M, Andreu EJ, Benito A, Arbona C, Sanz C, Benet I, et al. Blockade of the Bcr-Abl kinase activity induces apoptosis of chronic myelogenous leukemia cells by suppressing signal transducer and activator of transcription 5-dependent expression of Bcl-xL. J Exp Med 2000; 191:977-84; PMID:10727459; http://dx doi.org/10.1084/jem.191.6.977

65. de Groot RP, Raaijmakers JA, Lammers JW, Jove R, Koenderman L. STAT5 activation by BCR-Ab contributes to transformation of K562 leukemia cells. Blood 1999; 94:1108-12; PMID:10419904

66. Sillaber C, Gesbert F, Frank DA, Sattler M, Griffin JD. STAT5 activation contributes to growth and viability in Bcr/Abl-transformed cells. Blood 2000; 95:2118-25; PMID:10706883

67. Futami M, Hatano T, Soda Y, Kobayashi S, Miyagishi M, Tojo A. RNAi-mediated silencing of p190Bcr-Abl inactivates Stat 5 and cooperates with imatinib mesylate and 17-allylamino-17-demetoxygeldanamycin in selective killing of p190Bcr-Abl-expressing leukemia cells. Leukemia 2008; 22:1131-8; PMID:18368071; http://dx.doi.org/10.1038/leu.2008.60

68. Scherr M, Chaturvedi A, Battmer K, Dallmann I, Schultheis B, Ganser A, et al. Enhanced sensitivity to inhibition of SHP2, STAT5, and Gab2 expression in chronic myeloid leukemia (CML). Blood 2006; 107:3279-87; PMID:16278304; http://dx.doi.org/10. 1182/blood-2005-08-3087

69. Warsch W, Kollmann K, Eckelhart E, Fajmann S, Cerny-Reiterer S, Hölbl A, et al. High STAT5 levels mediate imatinib resistance and indicate disease progression in chronic myeloid leukemia. Blood 2011; 117:3409-20; PMID:21220747; http://dx.doi. org/10.1182/blood-2009-10-248211
70. Hoelbl A, Schuster C, Kovacic B, Zhu B, Wickre M, Hoelzl MA, et al. Stat 5 is indispensable for the maintenance of bcr/abl-positive leukaemia. EMBO Mol Med 2010; 2:98-110; PMID:20201032; http:// dx.doi.org/10.1002/emmm.201000062

71. Nelson EA, Walker SR, Weisberg E, Bar-Natan M, Barrett R, Gashin LB, et al. The STAT5 inhibitor pimozide decreases survival of chronic myelogenous leukemia cells resistant to kinase inhibitors. Blood 2011; 117:3421-9; PMID:21233313; http://dx.doi. org/10.1182/blood-2009-11-255232

72. Aboudola S, Murugesan G, Szpurka H, Ramsingh G, Zhao X, Prescott $\mathrm{N}$, et al. Bone marrow phosphoSTAT5 expression in non-CML chronic myeloproliferative disorders correlates with JAK2 V617F mutation and provides evidence of in vivo JAK2 activation. Am J Surg Pathol 2007; 31:233-9; PMID:17255768; http://dx. doi.org/10.1097/01.pas.0000213338.25111.d3

73. Wernig G, Kharas MG, Okabe R, Moore SA, Leeman DS, Cullen DE, et al. Efficacy of TG101348, a selective JAK2 inhibitor, in treatment of a murine model of JAK2V617F-induced polycythemia vera. Cancer Cell 2008; 13:311-20; PMID:18394554; http://dx.doi.org/10.1016/j.ccr.2008.02.009

74. Geron I, Abrahamsson AE, Barroga CF, Kavalerchik E, Gotlib J, Hood JD, et al. Selective inhibition of JAK2driven erythroid differentiation of polycythemia vera progenitors. Cancer Cell 2008; 13:321-30; PMID 18394555; http://dx.doi.org/10.1016/j.ccr.2008.02.017

75. Moriggl R, Sexl V, Kenner L, Duntsch C, Stangl K, Gingras $S$, et al. Stat 5 tetramer formation is associated with leukemogenesis. Cancer Cell 2005; 7:87-99; PMID: 15652752; http://dx.doi.org/10.1016/j.ccr.2004.12.010

76. Onishi M, Nosaka T, Misawa K, Mui AL, Gorman D, McMahon $\mathrm{M}$, et al. Identification and characterization of a constitutively active STAT5 mutant that promotes cell proliferation. Mol Cell Biol 1998; 18:3871-9; PMID:9632771

77. Kato Y, Iwama A, Tadokoro Y, Shimoda K, Minoguchi M, Akira S, et al. Selective activation of STAT5 unveils its role in stem cell self-renewal in normal and leukemic hematopoiesis. J Exp Med 2005; 202:169-79; PMID:15998795; http://dx.doi.org/10. 1084/jem.20042541

78. Chalandon Y, Jiang X, Christ O, Loutet S, Thanopoulou E, Eaves A, et al. BCR-ABL-transduced human cord blood cells produce abnormal populations in immunodeficient mice. Leukemia 2005; 19:442-8; PMID:15674417; http://dx.doi.org/10.1038/sj.leu 2403650

79. Rizo A, Horton SJ, Olthof S, Dontje B, Ausema A, van Os R, et al. BMI1 collaborates with BCR-ABL in leukemic transformation of human CD34+ cells. Blood 2010; 116:4621-30; PMID:20724541; http:// dx.doi.org/10.1182/blood-2010-02-270660

80. Bunting KD, Bradley HL, Hawley TS, Moriggl R, Sorrentino BP, Ihle JN. Reduced lymphomyeloid repopulating activity from adult bone marrow and fetal liver of mice lacking expression of STAT5. Blood 2002; 99:479-87; PMID:11781228; http://dx.doi.org/ 10.1182/blood.V99.2.479

81. Bradley HL, Hawley TS, Bunting KD. Cell intrinsic defects in cytokine responsiveness of STAT5-deficient hematopoietic stem cells. Blood 2002; 100:3983-9; PMID:12393407; http://dx.doi.org/10.1182/blood2002-05-1602

82. Bradley HL, Couldrey C, Bunting KD. Hematopoieticrepopulating defects from STAT5-deficient bone marrow are not fully accounted for by loss of thrombopoietin responsiveness. Blood 2004; 103:2965-72; PMID:15070672; http://dx.doi.org/10.1182/blood2003-08-2963 
83. Snow JW, Abraham N, Ma MC, Abbey NW, Herndier B, Goldsmith MA. STAT5 promotes multilineage hematolymphoid development in vivo through effects on early hematopoietic progenitor cells. Blood 2002; 99:95-101; PMID:11756158; http://dx.doi.org/ 10.1182/blood.V99.1.95

84. Snow JW, Abraham N, Ma MC, Bronson SK, Goldsmith MA. Transgenic bcl-2 is not sufficient to rescue all hematolymphoid defects in STAT5A/5Bdeficient mice. Exp Hematol 2003; 31:1253-8; PMID: 14662332; http://dx.doi.org/10.1016/j.exphem.2003. 09.014

85. Snow JW, Abraham N, Ma MC, Goldsmith MA Bone marrow transplant completely rescues hematolymphoid defects in STAT5A/5B-deficient mice. Exp Hematol 2003; 31:1247-52; PMID:14662331; http:// dx.doi.org/10.1016/j.exphem.2003.08.013

86. Couldrey C, Bradley HL, Bunting KDA. A STAT5 modifier locus on murine chromosome 7 modulates engraftment of hematopoietic stem cells during steady-state hematopoiesis. Blood 2005; 105:1476-83; PMID:15498858; http://dx.doi.org/10.1182/blood2004-06-2302

87. Zhu BM, McLaughlin SK, Na R, Liu J, Cui Y, Martin C, et al. Hematopoietic-specific Stat5-null mice display microcytic hypochromic anemia associated with reduced transferrin receptor gene expression. Blood 2008; 112:2071-80; PMID:18552213; http://dx.doi. org/10.1182/blood-2007-12-127480

88. Wang Z, Li G, Tse W, Bunting KD. Conditional deletion of STAT5 in adult mouse hematopoietic stem cells causes loss of quiescence and permits efficient nonablative stem cell replacement. Blood 2009; 113:4856-65; PMID:19258595; http://dx.doi.org/10. 1182/blood-2008-09-181107

89. Matikainen $S$, Sareneva $T$, Ronni $T$, Lehtonen A, Koskinen PJ, Julkunen I. Interferon-alpha activates multiple STAT proteins and upregulates proliferationassociated IL-2Ralpha, c-myc, and pim-1 genes in human T cells. Blood 1999; 93:1980-91; PMID:10068671

90. Matsumura I, Kitamura T, Wakao H, Tanaka H, Hashimoto K, Albanese C, et al. Transcriptional regulation of the cyclin D1 promoter by STAT5: its involvement in cytokine-dependent growth of hematopoietic cells. EMBO J 1999; 18:1367-77; PMID:10064602; http://dx.doi.org/10.1093/emboj/ 18.5.1367

91. Yip-Schneider MT, Horie M, Broxmeyer HE. Transcriptional induction of pim-1 protein kinase gene expression by interferon gamma and posttranscriptional effects on costimulation with steel factor. Blood 1995; 85:3494-502; PMID:7540064

92. Kozar K, Ciemerych MA, Rebel VI, Shigematsu H, Zagozdzon A, Sicinska E, et al. Mouse development and cell proliferation in the absence of D-cyclins. Cell 2004; 118:477-91; PMID:15315760; http://dx.doi. org/10.1016/j.cell.2004.07.025

93. Mikkers H, Nawijn $M$, Allen J, Brouwers C, Verhoeven E, Jonkers J, et al. Mice deficient for all PIM kinases display reduced body size and impaired responses to hematopoietic growth factors. Mol Cell Biol 2004; 24:6104-15; PMID:15199164; http://dx. doi.org/10.1128/MCB.24.13.6104-6115.2004

94. Mochizuki T, Kitanaka C, Noguchi K, Muramatsu T, Asai A, Kuchino Y. Physical and functional interactions between Pim-1 kinase and Cdc25A phosphatase. Implications for the Pim-1-mediated activation of the c-Myc signaling pathway. J Biol Chem 1999; 274:18659-66; PMID:10373478; http://dx.doi.org/ $10.1074 /$ jbc. 274.26 .18659

95. Bachmann M, Kosan C, Xing PX, Montenarh M, Hoffmann I, Möröy T. The oncogenic serine/threonine kinase Pim-1 directly phosphorylates and activates the G2/M specific phosphatase Cdc25C. Int J Biochem Cell Biol 2006; 38:430-43; PMID:16356754; http://dx.doi. org/10.1016/j.biocel.2005.10.010
96. Satoh Y, Matsumura I, Tanaka H, Ezoe S, Sugahara $\mathrm{H}$, Mizuki M, et al. Roles for c-Myc in self-renewal of hematopoietic stem cells. J Biol Chem 2004; 279: 24986-93; PMID:15067010; http://dx.doi.org/10.1074/ jbc.M400407200

97. Wilson A, Murphy MJ, Oskarsson T, Kaloulis K, Bettess MD, Oser GM, et al. c-Myc controls the balance between hematopoietic stem cell self-renewal and differentiation. Genes Dev 2004; 18:2747-63 PMID:15545632; $\quad$ http://dx.doi.org/10.1101/gad 313104

98. Yoshimoto G, Miyamoto T, Jabbarzadeh-Tabrizi S, Iino T, Rocnik JL, Kikushige Y, et al. FLT3-ITD upregulates MCL-1 to promote survival of stem cells inacute myeloid leukemia via FLT3-ITD-specific STAT5 activation. Blood 2009; 114:5034-43; PMID 19808698; http://dx.doi.org/10.1182/blood-2008-12196055

99. Xu M, Nie L, Kim SH, Sun XH. STAT5-induced Id-1 transcription involves recruitment of $\mathrm{HDAC} 1$ and deacetylation of C/EBPbeta. EMBO J 2003; 22:893 904; PMID:12574125; http://dx.doi.org/10.1093/ emboj/cdg094

100. Jankovic V, Ciarrocchi A, Boccuni P, DeBlasio T, Benezra R, Nimer SD. Id1 restrains myeloid commitment, maintaining the self-renewal capacity of hematopoietic stem cells. Proc Natl Acad Sci U S A 2007; 104:1260-5; PMID:17227850; http://dx.doi.org/10. 1073/pnas.0607894104

101. Fatrai S, Wierenga AT, Daenen SM, Vellenga E, Schuringa JJ. Identification of HIF2alpha as an important STAT5 target gene in human hematopoietic stem cells. Blood 2011; 117:3320-30; PMID:21263150; http://dx.doi.org/10.1182/blood-2010-08-303669

102. Wierenga AT, Vellenga E, Schuringa JJ. Maximal STAT5-induced proliferation and self-renewal at intermediate STAT5 activity levels. Mol Cell Biol 2008; 28:6668-80; PMID:18779318; http://dx.doi. org/10.1128/MCB.01025-08

103. Heath V, Suh HC, Holman M, Renn K, Gooya JM, Parkin S, et al. C/EBPalpha deficiency results in hyperproliferation of hematopoietic progenitor cells and disrupts macrophage development in vitro and in vivo. Blood 2004; 104:1639-47; PMID:15073037; http://dx.doi.org/10.1182/blood-2003-11-3963

104. Zhang P, Iwasaki-Arai J, Iwasaki H, Fenyus ML, Dayaram T, Owens BM, et al. Enhancement of hematopoietic stem cell repopulating capacity and self-renewal in the absence of the transcription factor C/EBP alpha. Immunity 2004; 21:853-63; PMID: 15589173; http://dx.doi.org/10.1016/j.immuni.2004. 11.006

105. Schepers H, Wierenga AT, van Gosliga D, Eggen BJ, Vellenga E, Schuringa JJ. Reintroduction of C/EBPalpha in leukemic CD34+ stem/progenitor cells impairs self-renewal and partially restores myelopoiesis. Blood 2007; 110:1317-25; PMID:17475913; http:// dx.doi.org/10.1182/blood-2006-10-052175

106. Spiekermann K, Pau M, Schwab R, Schmieja K, Franzrahe S, Hiddemann W. Constitutive activation of STAT3 and STAT5 is induced by leukemic fusion proteins with protein tyrosine kinase activity and is sufficient for transformation of hematopoietic precurso cells. Exp Hematol 2002; 30:262-71; PMID:11882364; http://dx.doi.org/10.1016/S0301-472X(01)00787-1

107. Harir N, Pecquet C, Kerenyi M, Sonneck K, Kovacic B, Nyga R, et al. Constitutive activation of Stat5 promotes its cytoplasmic localization and association with PI3-kinase in myeloid leukemias. Blood 2007; 109:1678-86; PMID:17038539; http://dx.doi.org/10. 1182/blood-2006-01-029918

108. Rosenbauer F, Wagner K, Kutok JL, Iwasaki H, Le Beau MM, Okuno Y, et al. Acute myeloid leukemia induced by graded reduction of a lineage-specific transcription factor, PU.1. Nat Genet 2004; 36:624-30; PMID: 15146183; http://dx.doi.org/10.1038/ng1361
109. Rosenbauer F, Owens BM, Yu L, Tumang JR, Steidl U, Kutok JL, et al. Lymphoid cell growth and transformation are suppressed by a key regulatory element of the gene encoding PU.1. Nat Genet 2006; 38:27-37; PMID:16311598; http://dx.doi.org/10.1038/ng1679

110. Luis TC, Naber BA, Roozen PP, Brugman MH, de Haas EF, Ghazvini M, et al. Canonical wnt signaling regulates hematopoiesis in a dosage-dependent fashion. Cell Stem Cell 2011; 9:345-56; PMID:21982234; http://dx.doi.org/10.1016/j.stem.2011.07.017

111. Pfitzner E, Jähne R, Wissler M, Stoecklin E, Groner B. p300/CREB-binding protein enhances the prolactinmediated transcriptional induction through direct interaction with the transactivation domain of Stat5, but does not participate in the Stat5-mediated suppression of the glucocorticoid response. Mol Endocrinol 1998; 12:1582-93; PMID:9773981; http://dx.doi.org/ 10.1210/me.12.10.1582

112. Gewinner C, Hart G, Zachara N, Cole R, BeisenherzHuss C, Groner B. The coactivator of transcription CREB-binding protein interacts preferentially with the glycosylated form of Stat5. J Biol Chem 2004; 279:3563-72; PMID:14597631; http://dx.doi.org/10. 1074/jbc.M306449200

113. Bakker WJ, van Dijk TB, Parren-van Amelsvoort M, Kolbus A, Yamamoto K, Steinlein P, et al. Differential regulation of Foxo3a target genes in erythropoiesis. Mol Cell Biol 2007; 27:3839-54; PMID:17353275; http://dx.doi.org/10.1128/MCB.01662-06

114. Kung AL, Rebel VI, Bronson RT, Ch'ng LE, Sieff CA, Livingston DM, et al. Gene dose-dependent control of hematopoiesis and hematologic tumor suppression by CBP. Genes Dev 2000; 14:272-7; PMID:10673499

115. Rebel VI, Kung AL, Tanner EA, Yang H, Bronson RT, Livingston DM. Distinct roles for CREB-binding protein and p300 in hematopoietic stem cell selfrenewal. Proc Natl Acad Sci U S A 2002; 99:14789 94; PMID:12397173; http://dx.doi.org/10.1073/pnas. 232568499

116. Chan WI, Hannah RL, Dawson MA, Pridans C, Foster D, Joshi A, et al. The transcriptional coactivator $\mathrm{Cbp}$ regulates self-renewal and differentiation in adult hematopoietic stem cells. Mol Cell Biol 2011; 31:5046-60; PMID:22006020; http://dx.doi.org/10. 1128/MCB.05830-11

117. Kranc KR, Schepers H, Rodrigues NP, Bamforth S, Villadsen E, Ferry H, et al. Cited2 is an essential regulator of adult hematopoietic stem cells. Cell Stem Cell 2009; 5:659-65; PMID:19951693; http://dx.doi. org/10.1016/j.stem.2009.11.001

118. Ikezoe T, Yang J, Nishioka C, Kojima S, Takeuchi A, Phillip Koeffler H, et al. Inhibition of signal transducer and activator of transcription 5 by the inhibitor of janus kinases stimulates dormant human leukemia CD34+ /CD38- cells and sensitizes them to antileukemia agents. Int J Cancer 2011; 128:2317-25; PMID:21128225; http://dx.doi.org/10.1002/ijc.25806

119. Cheng T, Rodrigues N, Shen H, Yang Y, Dombkowski D, Sykes M, et al. Hematopoietic stem cell quiescence maintained by p21cip1/waf1. Science 2000; 287:18048; PMID:10710306; http://dx.doi.org/10.1126/science. 287.5459.1804

120. Yu JH, Zhu BM, Wickre M, Riedlinger G, Chen W, Hosui A, et al. The transcription factors signal transducer and activator of transcription 5A (STAT5A) and STAT5B negatively regulate cell proliferation through the activation of cyclin-dependent kinase inhibitor 2b (Cdkn2b) and Cdkn1a expression. Hepatology 2010; 52:1808-18; PMID: 21038417; http://dx.doi.org/10.1002/hep.23882

121. Viale A, De Franco F, Orleth A, Cambiaghi V, Giuliani V, Bossi D, et al. Cell-cycle restriction limits DNA damage and maintains self-renewal of leukaemia stem cells. Nature 2009; 457:51-6; PMID:19122635; http://dx.doi.org/10.1038/nature07618 
122. Kaluz S, Kaluzová M, Stanbridge EJ. Regulation of gene expression by hypoxia: integration of the HIF-transduced hypoxic signal at the hypoxia-responsive element. Clin Chim Acta 2008; 395:6-13; PMID:18505681; http://dx.doi.org/10.1016/j.cca.2008.05.002

123. Takubo K, Goda N, Yamada W, Iriuchishima H, Ikeda E, Kubota Y, et al. Regulation of the HIF-1alpha level is essential for hematopoietic stem cells. Cell Stem Cell 2010; 7:391-402; PMID:20804974; http://dx. doi.org/10.1016/j.stem.2010.06.020

124. Simsek T, Kocabas F, Zheng J, Deberardinis RJ, Mahmoud AI, Olson EN, et al. The distinct metabolic profile of hematopoietic stem cells reflects their location in a hypoxic niche. Cell Stem Cell 2010; 7:380-90; PMID:20804973; http://dx.doi.org/10.1016/j.stem. 2010.07.011

125. Calvi LM, Adams GB, Weibrecht KW, Weber JM, Olson DP, Knight MC, et al. Osteoblastic cells regulate the haematopoietic stem cell niche. Nature 2003; 425:841-6; PMID:14574413; http://dx.doi.org/ 10.1038 /nature 02040

126. Rizo A, Vellenga E, de Haan G, Schuringa JJ. Signaling pathways in self-renewing hematopoietic and leukemic stem cells: do all stem cells need a niche? Hum Mol Genet 2006; 15(Spec No 2):R210-9; PMID:16987886; http://dx.doi.org/10.1093/hmg/ddl175

127. Schofield R. The relationship between the spleen colony-forming cell and the haemopoietic stem cell. Blood Cells 1978; 4:7-25; PMID:747780

128. Zhang J, Niu C, Ye L, Huang H, He X, Tong WG, et al. Identification of the haematopoietic stem cell niche and control of the niche size. Nature 2003; 425:836-41; PMID:14574412; http://dx.doi.org/10. 1038/nature02041
129. Rizo A, Dontje B, Vellenga E, de Haan G, Schuringa JJ. Long-term maintenance of human hematopoietic stem/progenitor cells by expression of BMI1. Blood 2008; 111:2621-30; PMID:18156489; http://dx.doi. org/10.1182/blood-2007-08-106666

130. Fatrai S, Schepers H, Tadema H, Vellenga E, Daenen SM, Schuringa JJ. Mucin1 expression is enriched in the human stem cell fraction of cord blood and is upregulated in majority of the AML cases. Exp Hematol 2008; 36:1254-65; PMID:18640764; http://dx.doi.org/10.1016/j.exphem.2008.04.015

131. Ahmad R, Raina D, Trivedi V, Ren J, Rajabi H, Kharbanda S, et al. MUC1 oncoprotein activates the IkappaB kinase beta complex and constitutive NFkappaB signalling. Nat Cell Biol 2007; 9:1419-27; PMID:18037881; http://dx.doi.org/10.1038/ncb1661

132. Huang L, Ren J, Chen D, Li Y, Kharbanda S, Kufe D. MUC1 cytoplasmic domain coactivates Wnt target gene transcription and confers transformation. Cancer Biol Ther 2003; 2:700-4; PMID:14688481; http://dx. doi.org/10.4161/cbt.2.6.610

133. Huang L, Chen D, Liu D, Yin L, Kharbanda S, Kufe D. MUC1 oncoprotein blocks glycogen synthase kinase 3beta-mediated phosphorylation and degradation of beta-catenin. Cancer Res 2005; 65:10413-22; PMID:16288032; http://dx.doi.org/10.1158/00085472.CAN-05-2474
134. Wen Y, Caffrey TC, Wheelock MJ, Johnson KR, Hollingsworth MA. Nuclear association of the cytoplasmic tail of MUC1 and beta-catenin. J Biol Chem 2003; 278:38029-39; PMID:12832415; http://dx.doi. org/10.1074/jbc.M304333200

135. Wei X, Xu H, Kufe D. Human MUC1 oncoprotein regulates $\mathrm{p} 53$-responsive gene transcription in the genotoxic stress response. Cancer Cell 2005; 7:167-78; PMID:15710329; http://dx.doi.org/10.1016/j.ccr.2005. 01.008

136. Rahn JJ, Chow JW, Horne GJ, Mah BK, Emerman JT, Hoffman P, et al. MUC1 mediates transendothelial migration in vitro by ligating endothelial cell ICAM-1. Clin Exp Metastasis 2005; 22:475-83; PMID:16320110; http://dx.doi.org/10.1007/s10585005-3098-x

137. Rahn JJ, Shen Q, Mah BK, Hugh JC. MUC1 initiates a calcium signal after ligation by intercellular adhesion molecule-1. J Biol Chem 2004; 279:29386-90; PMID: 15169768; http://dx.doi.org/10.1074/jbc.C400010200

138. Adams GB, Chabner KT, Alley IR, Olson DP, Szczepiorkowski ZM, Poznansky MC, et al. Stem cell engraftment at the endosteal niche is specified by the calcium-sensing receptor. Nature 2006; 439: 599-603; PMID:16382241; http://dx.doi.org/10.1038/ nature 04247
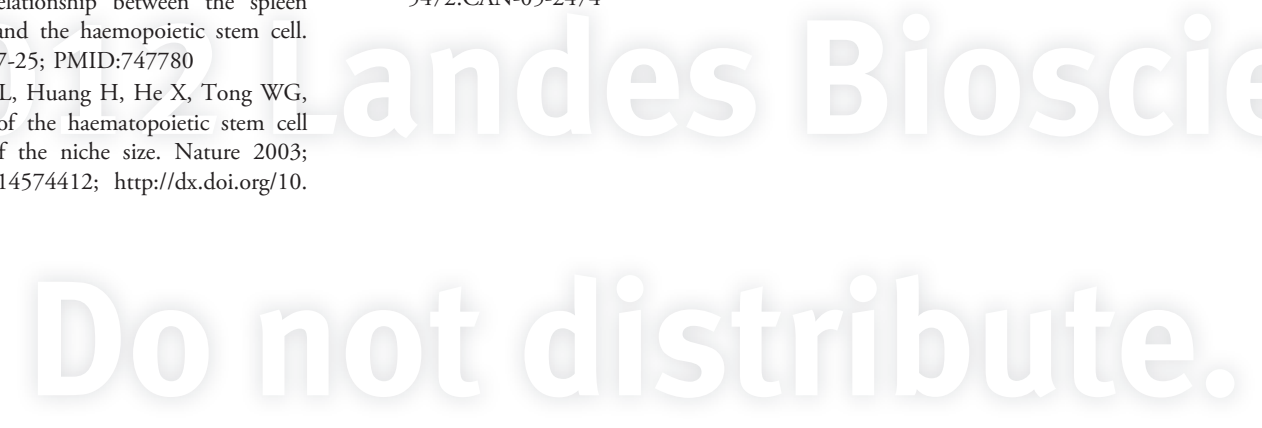